\title{
Impact of sarcopenia, sedentarism and risk of falls in older people's health self-perception
}

\author{
Impacto da sarcopenia, sedentarismo e risco de \\ quedas na percepção de saúde de idosos
}

\section{Impacto de sarcopenia, sedentarismo y riesgo de quedas en la percepción de salud de idosos}

\author{
Jaqueline Lima dos Santos $\circledast^{[a]}$, Cátia Trennepohl@[a], Carolina Böettge Rosa ${ }^{[b]}$, \\ Solange Beatriz Billig Garces ${ }^{\circledR a]}$, Jociane de Carvalho Myskiw ${ }^{[b]}$, Dinara Hansen Costa ${ }^{[a]}$
}

[a] Universidade de Cruz Alta (UNICRUZ), Cruz Alta, RS, Brazil

[b] Pontifícia Universidade Católica do Rio Grande do Sul (PUCRS), Porto Alegre, RS, Brazil

Abstract

Introduction: Sarcopenia, often associated with sedentarism, increases the risk of falls in older people, which may contribute to poorer health. Objective: This study sought to verify the impact of sarcopenia, sedentary lifestyle and risk of falls in older people's health self-perception. Method: This was an observational, descriptive, crosssectional study with a quantitative approach. The sample included 317 older people from the municipality of Cruz Alta, who underwent an assessment with specific instruments to evaluate the presence of risk of falls (Downton and Timed Up and Go - TUG) and sarcopenia (Manual Hold Force - MHF and Circumference of the Calf - CP). They

* JLS: BS, e-mail: a.jaquelinelima@gmail.com CT: Undergrad, e-mail: catia.trennepohl@hotmail.com CBR: PhD, e-mail: carolboettge@gmail.com SBBG: PhD, e-mail: sgarces@unicruz.edu.br JCM: PhD, e-mail: jociane.myskiw@pucrs.br DHC: PhD, e-mail: dhansen@unicruz.edu.br 
were also subjected to the International Physical Activity (IPAQ) and the Self-perception of Health questionnaires. Association between variables was performed using the Pearson chi-square test, with a 95\% confidence interval (CI). Results: In respect to TUG, 202 (63.7\%) older people presented an average risk of falls, and only 27 (8.5\%) presented a high risk of falls. However, Downton showed that a hundred older people (31.5\%) were at risk of falling. Sarcopenia as evaluated via CP and MHF was observed in 4.7\% (15) and 31.9\% older people, respectively. Regarding IPAQ 161 (50.8\%) participants were classified as active, while 156 (49.2\%) were classified as inactive. In regards to self-perceived health, 159 (50.2\%) older people evaluated their health condition as average or poor. Conclusion: Results suggest that older people's negative health self-perception is directly associated with predisposing factors for falls, such as sarcopenia and physical inactivity, as well as the presence of risk of falls (as evaluated by instruments that take into account risk factors and individual physical conditions).

Keywords: Sarcopenia. Sedentary Lifestyle. Risk Factors. Accidental falls.

\section{Resumo}

Introdução: A sarcopenia, muitas vezes associada à inatividade física, aumenta o risco para quedas em idosos, o que pode contribuir para piores condições de saúde. Objetivo: Esse estudo buscou verificar o impacto da sarcopenia, sedentarismo e risco de quedas na autopercepção de saúde dos idosos. Método: Caracteriza-se por ser um estudo observacional, descritivo, transversal com abordagem quantitativa. A amostra foi constituída por 317 idosos, do município de Cruz Alta, aos quais foram aplicados instrumentos para verificação do risco de quedas (Downton e Timed Up and Go -TUG), a presença de sarcopenia (Força da Preensão Manual - FPM e Circunferência da Panturrilha-CP), o questionário Internacional de Atividade Física (IPAQ) e para avaliar a percepção de saúde foi aplicando o questionário da Autopercepção de Saúde. A associação entre as variáveis foi realizada através do teste qui-quadrado de Pearson, com intervalo de confiança (IC) de 95\%. Resultados: Ao analisar resultados do TUG, constatou-se que 202 (63,7\%) idosos apresentaram risco baixo e apenas $27(8,5 \%)$ idosos apresentaram alto risco de quedas. Conforme avaliação de Downton, 100 (31,5\%) idosos apresentaram risco de queda. A sarcopenia avaliada através do teste da CP e FPM foi de 4,7\% (15) e 31,9\% idosos respectivamente. Referente ao IPAQ verificou-se que 161 (50,8\%) idosos são ativos e 156 (49,2\%) são inativos e na autopercepção de saúde 159 (50,2\%) avaliaram ter saúde média ou ruim. Conclusão: Os resultados sugerem que a autopercepção negativa da saúde dos idosos está diretamente associada a fatores que predispõe às quedas como a sarcopenia e a inatividade física, bem como a presença do risco de quedas avaliada através de instrumentos que levam em consideração fatores de risco e condições físicas dos indivíduos.

Palavras-chave: Sarcopenia. Sedentarismo. Fatores de Risco. Acidentes por Quedas.

\section{Resumen}

Introducción: La sarcopenia, a menudo asociada a la inactividad física, aumenta el riesgo de caídas en ancianos, lo que puede contribuir a peores condiciones de salud. Meta: Este estudio buscó verificar el impacto de la sarcopenia, sedentarismo y riesgo de caídas en la autopercepción de salud de los ancianos. Métodos: Se caracteriza por ser un estudio observacional, descriptivo, transversal con abordaje cuantitativo. La muestra fue constituida por 317 ancianos, del municipio de Cruz Alta, a los cuales se aplicaron instrumentos para verificar el riesgo de caídas (Downton y Timed Up and Go -TUG), la presencia de sarcopenia (Fuerza del Asalto Manual (FAM y Circunferencia de la Pantorrilla-CP), el cuestionario Internacional de Actividad Física (IPAQ) y para evaluar la percepción de salud fue aplicando el cuestionario de la Autopercepción de Salud. La asociación entre las variables fue realizada a través del test chicuadrado de Pearson, con intervalo de confianza (IC) del 95\%. Resultados: En el análisis de resultados del TUG, se constató que 202 (63,7\%) ancianos presentaron riesgo bajo y sólo 27 (8,5\%) ancianos presentaron alto riesgo de caídas. Conforme a la evaluación de Downton, 100 (31,5\%) ancianos presentaron riesgo de caída. La sarcopenia evaluada a través de la prueba de la CP y FAM fue de 4,7\% (15) y 31,9\% ancianos respectivamente. En el IPAQ se verificó que 161 (50,8\%) ancianos son activos y 156 (49,2\%) son inactivos y en la autopercepción de 
salud 159 (50,2\%) evaluaron tener salud media o mala. Conclusión: Los resultados sugieren que la autopercepción negativa de la salud de los ancianos está directamente asociada a factores que predisponen a las caídas como la sarcopenia y la inactividad física, así como la presencia del riesgo de caídas evaluada a través de instrumentos que tienen en cuenta factores de riesgo y condiciones físicas de los individuos.

Palabras clave: Sarcopenia. Estilo de Vida Sedentario. Factores de Riesgo. Accidentes por Caídas.

\section{Introduction}

The natural aging process, or senescence, is complex and multifactorial, due to its biological, evolutionary and genetic characteristics [1]. Senescence is characterized by harmful, progressive and cumulative alterations, with changes that compromise older people's physiological integrity and increase their vulnerability to pathologies [1].

The association between aging's natural progression and the presence of comorbidities has an important relationship with functional inability and the increase in the likelihood of older people becoming dependent [2]. Non-sedentary older people tend to present higher functional levels than sedentary people, given that physical activity tends to minimize harmful effects of aging [3].

Among natural changes that occur in the human body with time, Sgarbieri and Pacheco [1] emphasize that the main alterations involve the skeleton, the weights of organs, and the body's general composition. The amount of fat tissue increases, followed by a decrease in cell solids, minerals and water, resulting in muscle mass loss, reduction in bone tissue and loss of specific weight [1].

Another important aspect of aging is muscle mass loss due to a decrease in the number and size of muscular fibers, or due to the death of nerves that stimulate muscular contraction [1]. Such loss, associated with reduction in skeleton muscular function, is known as sarcopenia [4], a universal phenomenon with complex and multifactorial causes, as well as diverse outcomes $[4,5]$.

Sarcopenia is an important factor in older people's health, and one of its main causes is physical inactivity, as confirmed by Santos et al. [6], who found a strong relationship between sarcopenia and lack of mobility in 116 older people aged 80 years or more. Confirming this data, a research study carried out with 173 older women in an urban community in northeastern Brazil showed that insufficiently active older women aged 80 years or more-who had been admitted to a hospital at least once in the previous year, and presented functional dependence-had greater probability of being sarcopenic [7].

Therefore, the maintenance of functional ability and quality of life is paramount for an optimal aging progression. To this end, regular physical activity is considered a good option [3], since there is significant evidence that a physically active routine helps preserve older people's physical, mental and social functions [8].

It is very important for older people to be aware that their aging and illness processes are directly dependent on life style. Feelings of weakness and insecurity result from physical, psychological, emotional and social problems, leading to deteriorated functional performance and compromised general health self-perception, which in turn contribute to inactivity and higher risk of accidents $[9,10]$.

In evaluations of health condition, the general perception of health is one of the more commonly employed variables [11]. This is a global indicator, in which people consider possible illnesses that they might have and the impact they generate over their physical, social and mental well-being. The indicator also evaluates older people's perception of how their health might interfere with their longevity and quality of life (QL) [12].

Sarcopenia associated with neurological losses predisposes the reduction in skeleton muscular strength and body balance control, contributing to the occurrence of falls [13]. The latter has been linked to older age, sedentary life style and large consumption of continuous medication, and also to bad health selfperception [14]. In this context, studies aiming at evaluating variables associated with older people's bad health self-perception have been contributing to effective actions to promote this population's health and QL [15]. 
This study's goal was to verify the impact of sarcopenia, sedentarism and risk of falls over the health self-perception of older people in the municipality of Cruz Alta, located in the northwestern portion of the state of Rio Grande do Sul, Brazil.

\section{Methods}

This was an observational, descriptive and crosssectional study with a quantitative approach, carried out between October 2014 and May 2016. Its population was comprised of 1,345 older people registered in 11 Family Health Strategy units (ESF, Brazilian acronym), all of which had been assisted by Community Health Agents in the year previous to the beginning of this research. The sample was selected using convenience non-probability sampling, meaning that only older people found at home after two attempted visits were interviewed. Thus, out of a population of 1,345 older people, the final sample included 317 interviewees.

All in all, 428 older people were not found in their address informed, 312 were not found after two attempted visits, 104 died during the study period, and 184 were excluded due to preestablished exclusion criteria. Included individuals were 60 years old or more, had enrolled in the ESF of Cruz Alta-RS, and had used the town health system service in the year previous to the beginning of this research.

Individuals excluded were those who presented bone fractures in the last 6 months, had uncontrolled cardiovascular disease, lower than cut-off scores in the Mini-Mental State Examination (MMSE) [16] - to avoid including individuals who might have had cognitive difficulties in carrying out the tests-and those who could not perform the positions required by the test, used prosthesis or orthosis to aid their walking, were in bed or required a wheelchair to move around. Another excluded group was comprised of older people who had been submitted to surgical procedures in the right or left upper limbs during the last three months before data collection, those who reported pain when carrying out the test, and finally those who were not at home during the two attempted visits.

Older people were duly informed of the research; those who agreed to participate signed an Informed Consent Term (TCLE, Brazilian acronym) and took the MMSE to track down any cognitive damage. The MMSE served to evaluate their temporal and spatial orientation, recent memory, attention, evocation, calculation, as well as language and visual-spatial abilities [17]. Cut-off points were based on the study by Chaves and Izquierdo [16], developed in Rio Grande do Sul, which proposed cut-off points based on schooling, assigning 24 base points to older people with over 4 years of schooling.

After approval of the participant in the MMSE test, the interview was carried out using a scheme devised by the researchers to characterize the sample. The participants were asked about their age, sex, marital status, schooling and monthly income (sociodemographic data), as well as the presence of vertigo or dizziness (yes or no questions), self-perception of health (excellent, very good, good, average, bad), diagnosis of hypertension, osteoporosis or articulation diseases, and visual accuracy evaluation (health conditions). At this point, height and weight measures were taken for the calculation of Body Mass Index (BMI).

Participants were then invited to answer the International Physical Activity Questionnaire (IPAQ) [18] and the Downton Fall Risk Assessment Scale [19]. Next, physical evaluations were performed, including circumference of the calf (CP), manual hold force (MHF) and Timed Up and Go (TUG), and the results were properly recorded.

The physical activity level was evaluated using the long version of the International Physical Activity Questionnaire (IPAQ) for an ordinary week, adapted by Mazo and Benedetti [18]. Following the instructions of the IPAQ the individuals under evaluation were classified as active or inactive. Older people who were able to perform at least 150 weekly minutes of moderate activities were considered active [18].

Risk of falls was evaluated using the Downton Fall Risk Assessment, with a score ranging from 0 to 11 . Scores over 3 indicated risk of falls [19].

TUG [20] was used to evaluate older people's risk of falls. The time spent by the older person to stand up from an armless chair, walk three meters, turn 180 degrees, return and sit in the same chair was clocked. Clocking started when the older person moved their back away from the back of the chair, and finished when it touched the back of the chair again [20]. Results were classified as follows: 10 seconds, normal older people who are healthy, independent, and have no risk of falls; $11-20$ seconds, frail older people with disabilities, partial independence and low risk of falls; over 20 seconds, older people with considerable physical mobility deficits and significant risk of falls [21].

Sarcopenia was identified by measuring CP and MHF. To determine $\mathrm{CP}$, the left leg was measured with 
a measuring tape around its most protuberant part [22]. For both men and women, a circumference equal to or over 31 centimeters is considered suitable [5].

Manual hold force was obtained using a manual hydraulic dynamometer (JAMAR Hydraulic Hand Dynamometer $^{\circledR}$ - Model PC-5030J1, Fred Sammons, Inc., Burr Ridge, IL: USA), following the protocol recommended by the American Association of Hand Therapists [23]. The best score after three attempts involving each hand was recorded as the measure. The cut-off point was adjusted according to the participant's sex and BMI [24]. BMI was obtained by dividing the body weight $(\mathrm{kg})$ by the height in squared meters.

The self-perception of health indicator was obtained by asking participants: "how would you qualify your health in the last few days?" The five possible answers were excellent, very good, good, average, and bad.

Data analysis was carried out using Statistical Package for the Social Sciences (SPSS) version 22.0, for Windows. Continuous variables with normal distribution were described as mean and standard deviation, while categorical variables were expressed in absolute (n) and relative (\%) frequencies. In the categorical variable association analysis, the Pearson chi-square test was employed; analyses of adjusted residue and relative risk had a 95\% confidence interval (CI).

This study was approved by the PUCRS Ethics Committee under Opinion $\mathrm{n}^{\circ}$ 808.504 and CAAE 33364114.2 .0000 .5336 , and met the criteria set by the resolution of the National Health Council $(466 / 2012)$ that governs this type of research.

\section{Results}

Out of the 1,345 older people assisted by the FHS in the municipality of Cruz Alta - RS, 1,028 were excluded. Thus, the sample was comprised of 317 older people. Their age ranged from 60 to 90 years, with a $71.5 \pm 7.3$ average. Most older people had between 60 and 69 years of age (45.7\%), were women $(67.5 \%)$, married $(51.7 \%)$, sustained an average monthly income between one and two regional minimum wages, and had not concluded elementary school (Table 1).

To collect data regarding sarcopenia, the participants were physically evaluated through Circumference of the Calf, and only $4.7 \%$ (15) older people appeared to have sarcopenia. However, when the same variable was assessed using the MHF, 31.9\% older people were shown to have sarcopenia (Table 2).
Table 1 - Participants' socio-demographic and health characteristics $(\mathrm{n}=317)$

\begin{tabular}{|c|c|c|c|}
\hline & & $\mathbf{N}$ & $\%$ \\
\hline \multirow{2}{*}{ Sex } & Female & 214 & 67.5 \\
\hline & Male & 103 & 32.5 \\
\hline \multirow{4}{*}{ Age range } & 60 to 69 & 145 & 45.7 \\
\hline & 70 to 79 & 122 & 38.5 \\
\hline & 80 to 89 & 48 & 15.1 \\
\hline & 90 or + & 2 & 0.6 \\
\hline \multirow{5}{*}{ Marital status } & Married & 164 & 51.7 \\
\hline & Widow/widower & 107 & 33.8 \\
\hline & Single & 29 & 9.1 \\
\hline & Separated & 15 & 4.7 \\
\hline & Other & 2 & 0.6 \\
\hline \multirow{6}{*}{ Schooling } & Illiterate & 26 & 8.2 \\
\hline & Incomplete elementary school & 198 & 62.5 \\
\hline & Complete elementary school & 43 & 13.6 \\
\hline & Complete high school & 36 & 11.4 \\
\hline & Complete higher education & 12 & 3.8 \\
\hline & Specialization & 2 & 0.6 \\
\hline \multirow{2}{*}{ Hypertension } & Yes & 226 & 71.3 \\
\hline & No & 91 & 28.7 \\
\hline \multirow{2}{*}{ Osteoporosis } & Yes & 107 & 33.8 \\
\hline & No & 210 & 66.2 \\
\hline \multirow{2}{*}{$\begin{array}{l}\text { Articulation } \\
\text { disease }\end{array}$} & Yes & 144 & 45.4 \\
\hline & No & 173 & 54.6 \\
\hline \multirow{5}{*}{ Sight } & Very good & 8 & 2.5 \\
\hline & Good & 98 & 30.9 \\
\hline & Average & 146 & 46.1 \\
\hline & Bad & 58 & 18.3 \\
\hline & Very bad & 7 & 2.2 \\
\hline \multirow{2}{*}{$\begin{array}{l}\text { Vertigo/ } \\
\text { dizziness }\end{array}$} & Yes & 135 & 42.6 \\
\hline & No & 182 & 57.4 \\
\hline \multirow{5}{*}{ Income } & No income & 16 & 5.0 \\
\hline & 1 minimum wage & 212 & 66.9 \\
\hline & 2 minimum wages & 57 & 18.0 \\
\hline & 3 to 5 minimum wages & 23 & 7.3 \\
\hline & $5+$ minimum wages & 9 & 2.8 \\
\hline
\end{tabular}

Table 2 - Participants' sarcopenia, risk of falls, level of physical activity and health self-perception $(n=317)$

\begin{tabular}{llcc}
\hline \multirow{2}{*}{ Sarcopenia CP } & & N & \% \\
& Sarcopenic & 15 & 4.7 \\
& Normal & 302 & 95.3 \\
\hline \multirow{2}{*}{ Sarcopenia MHF } & Eutrophic & 216 & 68.1 \\
& Sarcopenic & 101 & 31.9 \\
\hline \multirow{2}{*}{ Health self-perception } & Excellent/Very Good/Good & 158 & 49.8 \\
& Average/Bad & 159 & 50.2 \\
\hline \multirow{3}{*}{ TUG* } & Without risk of falls & 88 & 27.8 \\
& Low risk of falls & 202 & 63.7 \\
\hline \multirow{2}{*}{ Downton } & High risk of falls & 27 & 8.5 \\
\hline \multirow{2}{*}{ IPAQ $^{* *}$} & Without risk of falls & 217 & 68.5 \\
& With risk of falls & 100 & 31.5 \\
\hline \multirow{2}{*}{$:{ }^{*}$} & Active & 161 & 50.8 \\
& Inactive & 156 & 49.2 \\
\hline
\end{tabular}

*: Timed Up and Go; **: International Physical Activity Questionnaire. 
Regarding health self-perception, 159 older people $(50.2 \%)$ considered their health average or bad, while $49.8 \%$ thought it was excellent, very good, or good (Table 2).

Older people's performance in the TUG test was used to evaluate their risk of falls. This test evaluates the time taken to walk three meters. The mean result was 13.42 ( \pm 5.14 ) seconds, indicating an average risk of falls. In the individual evaluation, 202 participants $(63.7 \%)$ were found to have a low risk of falls, and only 27 (8.5\%) were found to have a high risk of falls.
According to the Downton test, 100 (31.5\%) older people had risk of falls. This data can be seen in Table 2 along with the level of physical activity, which according to the IPAQ classified 161 (50.8\%) participants as active and 156 (49.2\%) as inactive.

As regards the association between the variables risk of falls, level of physical activity level and sarcopenia with health self-perception, a significant association was verified for: sarcopenia as measured by the MHF $(\mathrm{p}=0.003)$, risk of falls as measured by the Downton test ( $\mathrm{p}<0.001)$, and physical activity level $(\mathrm{p}=0.009)$ (Table 3$)$.

Table 3 - Association between older people's self-perception of health and sarcopenia, risk of falls, and physical activity level $(n=317)$

\begin{tabular}{|c|c|c|c|c|c|c|c|c|c|c|c|c|c|}
\hline \multicolumn{14}{|c|}{ Self-perception of health } \\
\hline & \multicolumn{2}{|c|}{ Excellent } & \multicolumn{2}{|c|}{ Very good } & \multicolumn{2}{|c|}{ Good } & \multicolumn{2}{|c|}{ Average } & \multicolumn{2}{|c|}{ Bad } & \multicolumn{2}{|c|}{ Total } & \multirow{2}{*}{$\begin{array}{c}\mathrm{P} \text { value } \\
\mathrm{n} \%\end{array}$} \\
\hline & $\mathrm{n}$ & $\%$ & $\mathrm{n}$ & $\%$ & $\mathrm{n}$ & $\%$ & $\mathrm{n}$ & $\%$ & $\mathrm{n}$ & $\%$ & $\mathrm{n}$ & $\%$ & \\
\hline \multicolumn{14}{|c|}{ IPAQ* } \\
\hline Active & 8 & 57.14 & 8 & 42.1 & 67 & 53.6 & 74 & 52.48 & 4 & 22.2 & 161 & 50.8 & \\
\hline Inactive & 6 & 42.86 & 11 & 57.9 & 58 & 46.4 & 67 & 47.52 & 14 & 87.8 & 156 & 49.2 & 0.124 \\
\hline Total & 14 & 100 & 19 & 100 & 125 & 100 & 141 & 100 & 18 & 100 & 317 & 100 & \\
\hline \multicolumn{14}{|c|}{ Downton } \\
\hline No risk & 12 & 85.7 & 17 & 89.5 & 101 & 80.8 & 78 & 55.3 & 9 & 50.0 & 217 & 68.5 & \\
\hline Risk present & 2 & 14.3 & 2 & 10.5 & 24 & 19.2 & 63 & 44.7 & 9 & 50.0 & 100 & 31.5 & $<0.001$ \\
\hline Total & 14 & 100 & 19 & 100 & 125 & 100 & 141 & 100 & 18 & 100 & 317 & 100 & \\
\hline \multicolumn{14}{|c|}{ TUG** } \\
\hline No risk & 10 & 71.4 & 5 & 26.3 & 38 & 30.4 & 33 & 23.4 & 2 & 11.1 & 88 & 27.8 & \\
\hline Low risk & 4 & 28.6 & 13 & 68.4 & 74 & 59.2 & 98 & 69.5 & 13 & 72.2 & 202 & 63.7 & 0.009 \\
\hline High risk & 0 & 0.0 & 1 & 5.3 & 13 & 10.4 & 10 & 7.1 & 3 & 16.7 & 27 & 8.5 & \\
\hline Total & 14 & 100 & 19 & 100 & 125 & 100 & 141 & 100 & 18 & 100 & 317 & 100 & \\
\hline \multicolumn{14}{|c|}{ MHF*** } \\
\hline Sarcopenia & 2 & 14.3 & 5 & 26.3 & 40 & 32.0 & 41 & 29.1 & 13 & 72.2 & 101 & 31.9 & \\
\hline Eutrophic & 12 & 85.7 & 14 & 73.7 & 85 & 68.0 & 100 & 70.9 & 5 & 27.8 & 216 & 68.1 & 0.003 \\
\hline Total & 14 & 100 & 19 & 100 & 125 & 100 & 141 & 100 & 18 & 100 & 317 & 100 & \\
\hline \multicolumn{14}{|c|}{$C P * * *$} \\
\hline Sarcopenia & 0 & 0.0 & 2 & 10.5 & 3 & 2.4 & 9 & 6.4 & 1 & 5.6 & 15 & 4.7 & \\
\hline Eutrophic & 14 & 100 & 17 & 89.5 & 122 & 97.6 & 132 & 93.6 & 17 & 94.4 & 302 & 95.3 & 0.343 \\
\hline Total & 14 & 100 & 19 & 100 & 125 & 100 & 141 & 100 & 18 & 100 & 317 & 100 & \\
\hline
\end{tabular}

*: International Physical Activity Questionnaire; **: Timed up and go; ***: Sarcopenia.

\section{Discussion}

The socio-demographic characteristics of older people who took part in this study were similar to those described in the literature, which refers to both community-dwellers and institutionalized older people. There is a predominance of female, married people with low schooling level and income [25-27]. These characteristics are related to greater risk of falls [28]. 
$\mathrm{CP}$ results confirmed another recent study evaluating sarcopenia in 37 community-dwelling older women, in which CP showed that $100 \%$ had very little muscle mass loss. Conversely, studies using measurements to evaluate sarcopenia associated with MHF, walking speed, skeleton muscle index and TUG showed that $19 \%$ older people had sarcopenia [29].

When sarcopenia was evaluated using MHF, the results showed most older people as eutrophic. This is not in agreement with another study, developed in the capital of the state of Paraná - Brazil, with older people enrolled in a Primary Health Unit. The study pointed out that older people frequently presented components of MHF reduction along with low levels of physical activity and walking speed [30]. In our sample, a lower number of elderly presenting sarcopenia when compared to other studies.

Analyzing the results of self-perception of health, older people that considered their health average or bad were observed to predominate. In this classification, the levels considered satisfactory were excellent, very good and good. We observed the same pattern in studies developed in the municipality of Passo Fundo-RS, Brazil, evaluating this variable in a sample of community-dwelling older people by the application of a questionnaire including personal, socio-demographic and health indicator data. Most older people evaluated their health as regular or good [31].

Another study in which older people did not consider their health excellent or very good was carried out in a town in the state of Bahia - Brazil, with older people assisted by the Family Health Strategy. Data was obtained using an instrument including socio-demographic questions, functional evaluation, self-report of chronic illnesses and health self-perception. The negative health self-perception found by the study was related to the existence of chronic illnesses [32].

We also evaluated risk of falls and physical activity level using three instruments: TUG, Downton and IPAQ. The TUG test allowed the observation that the mean time spent to accomplish the test showed predominance of average risk of falls. But, regarding risk-group classification using other means of evaluation, however, older people with low risk of falls appeared to be predominant. Thus, both evaluations demonstrated that the majority of the sample had some risk of falling. These results are similar to those of another study carried out with 39 older people, in which identified risk of fall classifications were average or low. This result was the benefits that the activities of daily life might promote in the morphological and neuromuscular adaptations, preventing a sharp reduction in elderly's motor abilities [33].

Another study developed with 102 communitydwellering older people evaluated using TUG showed different results from what was seen in this study. Only four (3.8\%) of the 102 participants accomplished the test in less than 10 seconds, 65 (63.7\%) finished it in 10 to 19 seconds, and $32.5 \%$ finished it in 20 seconds or more, showing that a large part of the studied population presented considerable risk of falls [34]. The Downton test, which quantifies the risk of falls while considering previous falls, medication, sensorial damage, mental condition and walking characteristics, provided a lower number of older people with risk of falls. This is unlike results found in institutionalized older people in the Campos Gerais region of the state of Parana, Brazil, who presented high risk of falls as assessed by the same instrument in older people who took five or more medicines [35].

The IPAQ results of physical activity found in this study showed a predominance of active older people. This result was also found in a study including community-dwelling older people in the municipality of Porto Alegre, in which participants' functional ability behaviors were identified. Most were classified as independent and physically active [36]. In another municipality, in the state of Rio Grande do Sul, Brazil, a study was carried out with community-dwelling older people divided into two comparison groups (active and insufficiently active older people). The study pointed out that older people who did some physical activity regularly presented better QL than those who were insufficiently active [3]. Thus, physical activity was shown to slow health degradation as a result of aging. It is worth pointing out that even though the group of active older people predominated, $49.2 \%$ were classified as inactive, which might have interfered in their health self-perception. In Minas Gerais, Brazil, a study aiming to investigate the association of health conditions and quality of life with physical activity in the leisure time of rural older people showed that negative perception of health was associated with physical inactivity [37].

The association verified between the variables health self-perception and presence of MHF-assessed sarcopenia $(p=0.003)$ suggests that sarcopenia does in fact negatively influence older people's perception 
of health. Among sarcopenic older people, most considered their health average or bad. Sarcopenia is a multifactorial condition with negative effects such as reduced mobility, cognitive decline, and early death [32], all of which might influence older people's health self-perception, as observed in our study.

We also found a certain degree of association between health self-perception and risk of falls as identified using the Downton test $(\mathrm{p}<0.001)$. Among the group with risk of falls, an overall negative evaluation of health predominated. This might be justified by the fact that risk of falls is associated with important losses related to intrinsic or individual risk factors. These might include foot alterations, poor balance, and proprioceptive deficit, which might have a negative effect on health [38].

The same association was observed between health self-perception and level of physical activity ( $p=0.009$ ), since TUG evaluates older people's risk of falls related to balance, walking speed and functional ability. These characteristics might be directly influenced by how active or sedentary an older person is. In addition, inactivity predisposes older people to chronic diseases that have negative effects over individuals' health conditions [39].

A study carried out in the Family Health Strategy of the municipality of João Pessoa-PB, Brazil, confirmed that negative health self-perception is linked to the occurrence of falls. The occurrence and frequency of falls and their association with health self-perception were evaluated using a questionnaire including sociodemographic characteristics and physical health. Fall events were most prevalent among female older people aged between 60 and 69 years, and among those who had a caregiver [40].

In the study carried out in the state of Bahia, elderly presented negative self-perception of health even when they were able to independently perform activities of daily living. Factors associated with worse perception of health were chronic diseases such as hypertension, heart disease, rheumatism, spine disease, and diabetes [32]. This may explain the mean results and poor health self-perception found in the studied sample, since a large portion of the sample had at least one chronic disease.

In agreement with the abovementioned studies, the results of this study show that factors such as pathologies, physical inactivity, sarcopenia and risk of falls might contribute to a negative health selfperception, thus influencing older people's well-being and quality of life.
Some of the limitations of this study refer to its sample selection technique (convenience sampling) and its cross-sectional design, which failed to consider other factors that might influence older people's health self-perception.

\section{Conclusion}

Results suggest that older people's negative health self-perception is directly associated with factors that predispose them to falls, such as sarcopenia and physical inactivity, as well as the presence of risk of falls as evaluated by instruments that take into consideration risk factors and the individual's physical conditions.

These findings may contribute to guiding preventive policies aimed at the promotion of health and the improvement of health conditions for older people, ensuring a population of older people with better health self-perception and reducing health system assistance costs, which are currently considered high.

\section{References}

1. Sgarbieri VC, Pacheco MTB. Healthy human aging: intrinsic and environmental factors. Braz J Food Technol. 2017;20.

2. Rossi AL, Pereira VS, Driusso P, Rebelatto JR, Ricci NA. Profile of the elderly in physical therapy and its relation to functional disability. Braz J Phys Ther. 2013;17(1):77-85.

3. Cordeiro J, Del Castillo BL, Freitas CS, Gonçalves MP. Effects of physical activity on declarative memory, functional capacity and quality of life in the elderly. Rev Bras Geriatr Gerontol. 2014;17(3):541-52.

4. Fielding RA, Vellas B, Evans WJ, Bhasin S, Morley JE, Newman AB, et al. Sarcopenia: an undiagnosed condition in older adults. Current consensus definition: prevalence, etiology, and consequences. International working group on sarcopenia. J Am Med Dir Assoc. 2011;12(4):249-56.

5. Cruz-Jentoft AJ, Baeyens JP, Bauer JM, Boirie Y, Cederholm T, Landi F, et al. Sarcopenia: European consensus on definition and diagnosis: Report of the European Working Group on Sarcopenia in Older People. Age Ageing. 2010;39(4):412-23. 
6. Santos VR, Gomes IC, Bueno DR, Christofaro DGD, Freitas Jr IF, IF, Gobbo LA. Obesity, sarcopenia, sarcopenic obesity and reduced mobility in Brazilian older people aged 80 years and over. Einstein. 2017;15(4):435-40.

7. Dutra T, Pinheiro PA, Carneiro JAO, Coqueiro RS, Fernandes MH. Prevalence and factors associated with sarcopenia in elderly women living in the community. Rev Bras Cineantropom Desempenho Hum. 2015;17(4):460-71.

8. Farinatti P. The regular practice of physical activities and the social involvement of the elderly person. Rev Bras Geriatr Gerontol. 2016;19(5):721-2.

9. Moimaz SAS, Almeida MEL, Lolli LF, Garbin CAS, Saliba NA. Aging: analysis of dimensions related to the elderly's perception. Rev Bras Geriatr Gerontol. 2009;12(3):361-75.

10. Fonseca CC, Chaves ECL, Pereira SS, Barp M, Moreira AM, Nogueira DA. Self-esteem and body satisfaction elderly practicing and non practicing physucal activity. Rev Educ Fis UEM. 2014;25(3):429-39.

11. Silva MF, Goulart NBA, Lanferdini FJ, Marcon M, Dias CP. Relationship between physical activity levels and quality of life of sedentary and physically active elderly. Rev Bras Geriatr Gerontol. 2012;15(4):634-42.

12. Borges AM, Santos G, Kummer JA, Fior L, Dal Molin V, Wibelinger LM. Self-perceived health in elderly living in a city in Rio Grande do Sul state. Rev Bras Geriatr Gerontol. 2014;17(1):79-86.

13. Guccione AA, Wong RA, Avers D. Fisioterapia geriátrica. Rio de Janeiro: Guanabara Koogan; 2013.

14. Gasparotto LPR, Falsarella GR, Coimbra AMV. Falls in elderly: basic concepts and updates of research in health. Rev Bras Geriatr Gerontol. 2014;17(1):201-9.

15. Vagetti GC, Moreira NB, Barbosa Filho VC, Oliveira V, Cancian CF, Mazzardo O, et al. Aspects of quality of life associated with self-rated health: a study of elderly women of a physical activity program in low-income neighborhoods in Curitiba in the state of Paraná, Brazil. Cienc Saude Coletiva. 2013;18(12):3483-93.
16. Chaves ML, Izquierdo I. Differential diagnosis between dementia and depression: a study of efficiency increment. Acta Neurol Scand. 1992;85(6):378-82.

17. Folstein MF, Folstein SE, McHugh PR. "Mini-mental State": a practical method for grading the cognitive state of patients for the clinician. J Psychiatr Res. 1975;12(3):189-98.

18. Mazo GZ, Benedetti TRB. Adaptation of the international physical activity questionnaire for the elderly. Rev Bras Cineantropom Desempenho Hum. 2010;12(6):480-4.

19. Downton JH. Falls in the elderly. Londres: Hodder Arnold; 1993.

20. Podsiadlo D, Richardson S. The timed "Up and Go": a test of basic functional mobility for frail elderly persons. J Am Geriatr Soc. 1991;39(2):142-8.

21. BischoffHA, Stähelin HB, Monsch AU, Iversen MD, Weyh $A$, von Dechend, M, et al. Identifying a cut-off point for normal mobility: a comparison of the timed 'up and go' test in community-dwelling and institutionalised elderly women. Age Ageing. 2003;32(3):315-20.

22. World Health Organization (WHO). Physical status: the use and interpretation of anthropometry. Geneva: World Health Organization. 1995 [cited 2018 Jun 14]. Available from: http://tinyurl.com/y4dy4vby.

23. Richards LG, Olson B, Pamiter-Thomas P. How forearm position affects grip strength. Am J Occup Ther. 1996;50(2):133-8.

24. Fried LP, Tangen CM, Walston J, Newman AB, Hirsch C, Gottdiener J, et al. Frailty in older adults: evidence for a phenotype. J Gerontol A Biol Sci Med Sci. 2001;56(3):M146-56.

25. Antes DL, d'Orsi E, Benedetti TRB. Circumstances and consequences of falls among the older adults in Florianopolis. EpiFloripa Idoso 2009. Rev Bras de Epidemiol. 2013;16(2):469-81.

26. Fhon JRS, Rosset I, Freitas CP, Silva AO, Santos JLF, Rodrigues RAP. Prevalence of falls among frail elderly adults. Rev Saude Publica. 2013;47(2):266-73. 
27. Mezari MC, Avozani TV, Bruscato NM, Moriguchi EH, Raffone AM. Study of the functionality, prevention the falls and health promotion in elderly people living at the Veranópolis-RS. RBCEH. 2012;9(1):129-42.

28. Rosa TSM, Moraes AB, Peripolli A, Santos Filha VAV. Epidemiologic profile of elderly people who died because of falls in Rio Grande do Sul state, Brazil. Rev Bras Geriatr Gerontol. 2015;18(1):59-69.

29. Paula JA, Wamser EL, Gomes ARS, Valderramas SR, Cardoso Neto J, Schieferdecker MEM. Analysis of methods for detecting sarcopenia in independent community-dwelling elderly women. Rev Bras Geriatr Gerontol. 2016;19(2):235-46.

30. Lenardt MH, Carneiro NHK, Binotto MA, Willig MH, Lourenço TM, Albino J. Frailty and quality of life in elderly primary health care users. Rev Bras Enferm. 2016;69(3):448-53.

31. Borges AM, Santos G, Kummer JA, Fior L, Dal Molin V, Wibelinger LM. Self-perceived health in elderly living in a city in Rio Grande do Sul state. Rev Bras Geriatr Gerontol. 2014;17(1):79-86.

32. Silva IT, Pinto Junior EP, Vilela ABA. Self-perceived health of older people living in a state of residence Rev. Bras. Geriatr. Gerontol. 2014;17(2):275-87.

33. Lopes MLV, Santos JPM, Fernandes KBP, Rogério FRPG, Freitas RQ Pires-Oliveira DAA. Relation of plantar pressure and range of movement of the lower limbs with the risk of falls in older women. Fisioter Pesqui. 2016;23(2):172-7.

34. Bretan O, Silva Júnior JE, Ribeiro OR, Corrente JE. Risk of falling among elderly persons living in the community: assessment by the Timed up and go test. Braz J Otorhinolaryngol. 2013;79(1):18-21.
35. Sousa JAV, Stremel AIF, Grden CRB, Borges PKO, Reche PM, Silva JHO. Risk of falls and associated factors in institutionalized elderly. Rev Rene. 2016;17(3):416-21.

36. Boggio ESB, Santos FC, Souza CM, Silva MF, Rosa PV, Rosa LHT. Analysis of factors affecting the functional capacity of elderly residents in a community in Porto Alegre. Estud Interdiscipl Envelhec. 2015;20(1):189-203.

37. Pegorari MS, Dias FA, Santos NMF, Tavares DMS. Practice of physical activity among older of leisure in rural area: health conditions and quality of life. Rev Educ Fis UEM. 2015;26(2):233-41.

38. Costa AGS, Araujo TL, Oliveira ARS, Morais HCC, Silva VM, Lopes MVO. Risk factors for falls in the elderly. Rev Rene. 2013;14(4):821-8.

39. Silva EC, Duarte NB, Arantes PMM. Study of relationship between level of physical activity and risk of falls in older women. Fisioter Pesq. 2011;18(1):23-30.

40. Dantas EL, Brito GEG, Lobato IAF. Prevalence of falls in elders ascribed to the family health strategy of the city of João Pessoa, Paraíba. Rev APS. 2012;15(1):67-75.
Received in $07 / 26 / 2018$ Recebido em 26/07/2018 Recibido en 26/07/2018

Approved in 01/09/2019 Aprovado em 09/01/2019 Aprobado en 09/01/2019 